\title{
Personality and territoriality in theory and in Belgium
}

\author{
Helder De Schutter
}

KU Leuven

Language policy debates regularly refer to the principles of personality and territoriality. Yet the precise meaning of these principles remains unclear. In this contribution, I conceptualize these principles as poles of a continuum between official bilingualism (instantiating the personality principle) and official unilingualism (exemplifying the territoriality principle), with a mixed regime in between (which grants a certain territorial primacy to a language, but allows exceptions based on linguistic affiliation). The question of the determination of particular points on the continuum cannot be separated from the metaterritorial question of the boundaries of the units within which those principles apply. Application of this 'continuum model' to Belgium draws attention to three language-political regimes. The first invokes a strict personality principle (Brussels). The second follows the strict territoriality principle (almost all municipalities in Flanders and Wallonia). The third is a mixed regime (a total of 27 'municipalities with facilities' where one language enjoys primacy but speakers of another language enjoy certain linguistic 'facilities'). The article also analyses the manner in which these regimes were historically established in Belgium in combination with a delineation of the language border and the division of the country into four language areas.

Keywords: linguistic justice, language policy, territoriality principle, Brussels, Belgium

\section{Introduction}

Language policy debates frequently refer to the principles of personality and territoriality. When language policy follows the personality principle, language rights are said to accrue to people. When language policy instead adheres to the territoriality principle, language rights are said to be territorially defined. 
In this contribution, I address two matters. In section two I show that this conceptualization of the personality-territoriality distinction is analytically confusing because it allows an officially multilingual territorial unit to be theorized as an instance of both personality and territoriality. I therefore propose an alternative 'continuum model' which works with two poles - the pure personality principle mandating official multilingualism and the pure territoriality principle mandating official monolingualism - and various points in between.

In section three, I apply this continuum model to the historical and current language-political situation of Belgium. I show how most of the territory of Belgium exhibits the territoriality principle, how a small proportion of it (the 'communautés à facilités') is situated on the continuum between territoriality and personality, and how its bilingual language area, Brussels, is an illustration of the personality pole of the continuum. ${ }^{1}$

\section{The continuum model}

Today, the principles of personality and of territoriality are familiar references in language policy debates. The two terms were coined for the language policy field by the Canadian Royal Commission on Bilingualism and Biculturalism (1967), and Kenneth McRae's subsequent work (especially see also McRae, 2007). These terms were later picked up by a large number of scholars, notably by advocates of (versions of) the territoriality principle including Jean Laponce (1987), Philippe Van Parijs (2011) and François Grin (2011), but also by advocates of (versions of ) personality (Patten, 2003; Réaume, 2003). Today personality and territoriality have become standard terms in academic analyses over language (see Burckhardt, Coakley and Marácz, 2021) but also in the public debate of several officially multilingual countries, including Belgium. The meanings of the two concepts are not always perspicuous, though, and their use is not consistent across the various researchers. In this first section, I attempt to bring some conceptual clarity by recalibrating the distinction between the two terms.

To start with, it is important to distinguish the question of what the right language policy is from the question of who holds the legal authority to make such language policies. An example of the latter is Karl Renner's defense of nonterritoriality (or personality) for the Austro-Hungarian Empire in 1899. Renner proposed a conception of non-territorial autonomy (embedded in a federal solution) as authority: in his solution, distinct national-cultural-linguistic groups that

1. I owe thanks to Till Burckhardt, John Coakley, László Marácz and an anonymous reviewer for helpful comments on an earlier draft. 
share the same territory are entitled to linguistic and cultural self-determination, exercised in distinct non-territorial parliaments. A member of the Czech nation, for instance, could as a result be subject to different rules than a member of the German nation, despite the fact that these two people may live in the same city (Renner, 2005 [1899]). In contrast to personal authority proposals, territorial authority models grant nations jurisdiction over territories, as advocated for instance by Will Kymlicka (2001).

But the normative debate over language policy is concerned not with the authority to wield language policy but with the content of language policy itself. It is concerned with answering questions such as 'Are French speakers in Ontario entitled to public education in French?' Or: 'can Dutch speakers in Wallonia expect to be addressed by city administrators in Dutch?'2 So for the remainder of this paper, my focus is on the content of language policy.

What, then, do territoriality and personality refer to as principles determining the content of language policy? In my proposed conceptual distinction between territoriality and personality, two issues are involved: (1) the language regime and (2) the borders within which that language regime is implemented.

\subsection{The language regime question}

The first and most important issue is the question of institutional recognition within a given territorial unit, such as a country (e.g. Canada) or a territorial subset of the country (e.g. the province of Québec). In what I will call a territorialitybased language policy regime, institutional recognition is limited to one language. This language enjoys public status: all publicly subsidized schools function in it, civil servants communicate in it with citizens, and citizens only get official documents in that language. In such a regime, there is one public language operative on the territory, and all inhabitants are to publicly adapt to it. On the territory in which this principle operates, institutional unilingualism is at work.

In what I will call a personality-based language policy regime, speakers of various language groups enjoy language rights and benefits on the same territory. The operative personality principle here installs institutional bi- or multilingualism. Both languages enjoy equal public status: both are languages of public education

2. Réaume refers to the authority conception as 'the question of jurisdiction over language matters' (2003, p. 275). Similarly, Patten calls the authority conception of territoriality 'jurisdictional territoriality' (Patten, 2003, pp.300-301). 
and of state communication. ${ }^{3}$ Indeed, all public institutions uphold these two as the languages in which services are provided. Rather than approaching the entire population of the territory in the same language, public services adapt to (groups of) persons based on their language needs and preferences: within the territory, the state (unit) guarantees equal public recognition to both groups.

While distinct from it, this discussion over language policy is philosophically similar to the discussion over language authority. In the authority discussion, Renner defended personality as the means of delineating and exercising legal authority: one's political membership as regards cultural and linguistic affairs is determined not by where one finds oneself, but by the group to which one chooses to belong (Renner, 2005, p. 20). Thinking this through to its logical extreme allows us to imagine a world where political membership would depend solely on individual affiliation. One can use the authority of the Catholic Church over individual Catholics as a non-political analogue: wherever a catholic resides - in any country, in the High Seas, even on the moon - that Catholic is subject to the Pope's authority. So, the Pope exercises ecclesiastical authority over Church members in a non-territorial fashion.

But that is not how mankind has organized itself politically. We could have opted for a non-territorial political world but we have not: political authority is organized territorially. Each state rules over all the people who find themselves on the state's territory, and with few exceptions such as Antarctica, all land has been divided into states. All who are present on a state's territory - whether they are citizens, non-citizen residents or tourists - are subject to the legal rules of that state.

This discussion over personal and territorial authority is relevant for theorizing about personal or territorial language policy regimes because a personalitybased policy regime also targets all the individuals who belong to a certain group, and a territoriality-based policy regime also targets all the individuals who are located in a given territorial unit. The personality-based language policy regime makes the state reach out to individuals in their own language (if that language is an official language). ${ }^{4}$ The territoriality-based regime makes the state reach out to the population in the one official language of the territory. Linguistic personality targets individuals on the basis of their linguistic affiliation; linguistic territoriality treats everyone on the territory linguistically in the same way.

3. For ease of reference, I will take as the standard case a territorial unit with two language groups, but whenever I use the term bilingualism, the example could be adapted to include multilingualism.

4. The personality principle still needs to determine which language(s) will be on equal institutional footing. It could restrict public recognition to a few languages. In Brussels, for instance, Dutch and French enjoy equal recognition but other languages receive no such standing. 
What the distinction comes down to, then, is whether a policymaking unit prescribes institutional monolingualism or institutional bi- or multilingualism on the territory. If only one language is recognized, the linguistic territoriality principle is in vogue; if two or more languages enjoy equal public status, the linguistic personality principle rules. ${ }^{5}$

In my view, this conceptual distinction between territoriality and personality is superior to an existing, dominant view that defines the oppositions as follows:

the principle of territoriality involves the application of language rules according to territorial units; the principle of personality involves their application according to the linguistic status or affiliation of the person or persons concerned.

(McRae, 1975, p.40)

Kenneth McRae's seminal work on territoriality and personality has been crucial to the development of conceptual and normative theorizing over the two principles. But McRae's definition of territoriality as demanding that the language rules depend on the territory suffers from an important weakness: it does not stipulate whether those language rules prescribe institutional unilingualism or bilingualism. As Denise Réaume has correctly noted,

since every state's jurisdiction is defined territorially, every country's language policy is to this extent territorial. By this reckoning it is hard to imagine what would count as a non-territorial policy.

(Réaume, 2003, p.275)

Indeed, in the territorial authority system in vogue in the contemporary world, all policy rules depend on a territory. ${ }^{6}$ Even the personality policy regime has to be applied in a specific territorial unit. That unit could be the country-wide territorial unit, such as Canada, or it could be a sub-state territorial unit, such as Brussels. In both cases, also, the personalistic policy principle makes rules that depend on the territory in question: the right to public schools in French that French speakers enjoy in Canada (where numbers warrant), for instance, are not enjoyed by them in the territory of the United States; and the rights of Dutch speakers

5. It is possible, though, that distinct jurisdictional units (e.g. the federal and the local units) apply their own language policies to the same territory, resulting in intraterritorially competing language policies.

6. In the opening paragraph of his article, McRae provides a clue to avoiding this critique, when he writes that under a territoriality principle, language rules 'depend solely on the territory in question' (1975, p.33; my emphasis). This solely leaves theoretical room to hold that under a principle of personality, the rules of language also depend on the territory, but not solely so: the rules depend also on other criteria, whereas territoriality (as a policy regime) treats everyone on the territory identically from a linguistic point of view. Still, McRae does not discuss the solely, and this potential way out also does not solve the second critique developed below. 
in Brussels to services in Dutch are not enjoyed by them in Wallonia. So, distinguishing the two policy models by recourse to the territorial or non-territorial nature of the authority of the rule does not allow us to conceptualize personality without falling back on territoriality.

Moreover, the problem for the definition is not just that personality policy regimes are also territorial; in addition, it is also problematic that McRae's definition of territoriality allows for institutional bilingualism. Since on this definition a language regime is based on the territoriality principle if the language rules depend on the territory, a territorial unit that chose to organize its language rules in such a way that two or more language groups on the territory receive language rights would still qualify as one that abides by the territoriality principle. In other words, for McRae's definition of territoriality, an institutionally bilingual regime still counts as a territoriality-based one. This possibility is explicitly recognized by McRae (1975, p. 41). But then, again, the distinction with personality vanishes. For example, McRae argues, correctly in my view, that 'in the bilingual capital area of Brussels the personality principle applies' (1975, p.46). But his analysis would equally allow for stating that in Brussels a territoriality principle with institutional bilingualism applies. That is indeed how some theorists (such as Van Parijs, 2011, p. 154; Van der Jeught, 2017, p. 181) understand the Brussels capital language area - as an expression of the territoriality principle with official bilingualism but, again, it is then not clear what it would mean for Brussels to have a personality regime.

In short: if territoriality means that the language rules depend on the territory, then, firstly, all personalistic language policy regimes exhibit territoriality and, secondly, territoriality includes personality. That is why I propose to limit the application of the term territoriality - as a policy regime - to those territorial units where institutional monolingualism applies: one official language per territory that enjoys recognitional dominance on that territory. What determines the language in which the government speaks to an inhabitant is his or her sheer presence on the territory. Personality, on the other hand, picks out the various speakers of two or more language groups within a given territory and provides services in their own language. What determines whether one gets language rights on the personality principle, then, is not only presence on the territory, but also one's linguistic affiliation: the personality principle realizes equal recognition for the official languages on the territory

Yet, if territoriality really comes down to institutional unilingualism in a territorial unit, and personality means institutional bi- or multilingualism in a territorial unit, then should we not avoid those terms altogether, and replace them by what they really imply, institutional unilingualism or multilingualism, or else, linguistic monism versus linguistic pluralism? While I think such a move would 
be warranted, I see three reasons for keeping territoriality and personality. First, words are just labels to refer to concepts. As long as we keep the concepts clear, whatever words are commonly in use can continue to be used. Second, keeping the territoriality term allows us to see the intrinsic connection between (official) language and territory sought after by its advocates. This is clear from its two most ardent supporters: Jean Laponce and Philippe Van Parijs. Laponce states unequivocally: 'if a minority language wishes to survive, its best insurance policy rests in territoriality and border control' (1987, p. 266). Van Parijs has exhorted language groups to

'grab a territory', which 'consists in allowing each of them to be 'the King' in some part, large or small, of the EU's territory, thereby making its own survival secure and giving a privilege, within the limits of that territory, to the people who have as a mother tongue the language to which that territory has been ascribed.

(Van Parijs, 2004, pp.142-144)

Both argue for a strict connection between language and territory. That in itself warrants the maintenance of the term 'territoriality'. Third, as I indicated above, territoriality does mean that the citizen is to adapt to the territory's official language, and personality means that the regional policy is to adapt to the person. Therefore, while the linguistic territoriality principle is not identical to an institutional monolingualism principle, it does imply it. The same holds for the personality principle's relation to instititutional bilingualism.

My proposed way of understanding the two concepts in respect of their institutional implications - as institutional unilingualism or institutional bi-or multilingualism - helps to understand that, really, these two positions are poles on a continuum. On the continuum, various points exist between strict territoriality and strict personality.

For instance, it seems absurd to hold that the smallest crack in a territorialitybased regime would make that regime fully personalistic. Imagine we have a territorial unit with two language groups, but where the linguistic territoriality principle is implemented - only one of the two languages enjoys public recognition and the public schools operate only in that language. Now imagine that a new policy is adopted that allows for just one month of public education in the other language on the territory in the first year of primary education: when entering primary school, pupils with the unrecognized language as native tongue are now addressed by teachers in their native tongue, as a temporary, one-month, linguistic cushion to better ease them into the educational system that beyond that month operates uniquely in the other language. Clearly this is a breach in a linguistic territoriality regime. An element of personality is now introduced. But the resulting regime is still a long way from a full personality-based regime with equal 
language recognition for both groups. In section three, I will explain how such an in-between 'mixed regime' exists in Belgium. Even theorists of territoriality allow for exceptions: Van Parijs proposes for instance that a small part of the territorial units be transformed into 'linguistically free zones' where the coerciveness of the territoriality principle could be relaxed by allowing high-skilled immigrants and their families to settle there without being expected to learn the local language (2011, p.163).

Conversely, any deviation from strict equality of recognition to the benefit of one of the languages causes the regime to move in the direction of territoriality. ${ }^{7}$ But that does not mean it then immediately matches the territoriality principle in full: it just constitutes a move on the continuum between personality and territoriality.

The two poles of the continuum, then, are pure personality with equal recognition and pure territoriality with strict institutional unilingualism. In between are many possibilities. The weaker the provisions for territoriality, the stronger the personality dynamic, at least in theory. Conversely, any move away from equality will lead to status inequality: one language gets public priority and, consequently, others are institutionally subordinated. In section three, I will identify some points in between the two poles in Belgium.

\subsection{The language border question}

Above I mentioned that there are two issues involved in speaking of personality and territoriality. The first is language policy within a specific territorial unit, which occupies a point on the continuum between official monolingualism and multilingualism. The second concerns the question of how to delineate territorial units. Should we subdivide a multilingual state into smaller sub-state territorial units, and, if so, how should these borders be drawn?

All territorial units - whether they are states or smaller units such as Canadian provinces, Swiss cantons, Ethiopian regional states, and Belgian regions have borders. So, apart from the question of the language policy regime that prevails within a given set of borders, there is also the question of how the borders within which such a regime will be implemented are to be drawn. Since indeed

7. To be precise here, we would need to further articulate the equal recognition ideal behind the personality regime. Different candidate principles for equal recognition can be identified, including 'per capita equality' (Patten, 2014, p. 200) and equality as 'equal services' (De Schutter, 2017, p.78). For the purpose of identifying the personality pole, I think we can be ecumenical about which principle best embodies the equality ideal of personality. 
all policies - even those adhering to the personality principle - necessarily have a territorial basis, we can call this second issue the metaterritorial one.

Here, too, this metaterritorial question is not an issue of the authority to decide over language policy: the question is not who has the legal authority to draw the boundaries (although that question is important as well). Like the previous question on the choice of language regime within a territorial unit, the metaterritorial question is one of policy: in respect of what principles are language borders (of the territorial units within which language specific regimes will apply) to be drawn up?

Imagine being presented with all available Belgian demolinguistic data as well as with a Belgian map on which no official language borders are drawn yet. The following question is asked: 'how should we solve the language borders issue in such a way that linguistic justice is achieved?' You know that within the borders that you draw a language regime will be implemented. If you draw just one border around the entire territory of Belgium without any sub-state territorial divisions, the next question will be what the appropriate regime will be (personality, territoriality to the advantage of one language, or somewhere in between). Would you then draw multiple sub-state borders? If so, where and how many?

Different candidate principles for delineating territorial units can be invoked here:

- One solution is to mark off territories that are as linguistically homogeneous as possible: here one seeks to draw boundaries around language groups.

- A second solution is to make borders cut across language groups, creating internally linguistically heterogeneous territorial units. This could be done either by drawing no intra-state language borders and recognizing just one state-wide territorial unit, or by drawing multiple language borders that cut across the groups.

Note that those who defend personality as a language policy principle might be indifferent on this metaterritorial issue. However, a defender of a territorialitybased regime will not be indifferent, and will strongly favor the first solution. Indeed, for a defender of linguistic territoriality who endorses protection of language groups, it is vital that one pursues the combination of the territoriality principle in the policy regime discussion with the metaterritorial principle of drawing boundaries around language groups. This is what centrally motivates the proposals of Laponce and Van Parijs. Drawing boundaries around only bilingual zones would forfeit their reason for implementing linguistic territoriality: to protect weaker, vulnerable languages from assimilation or undignified treatment. As we shall see in section three, a similar motivation was also behind the Flemish position in support of territoriality in Flanders. 
It should be noted that someone might also choose territorial institutional monolingualism for non-identity reasons that have nothing to do with withstanding assimilation or promoting dignity. They might for instance favor the linguistic territoriality principle as a policy regime for reasons of democratic and institutional efficiency or socio-economic equality. This appears to be for example what drives Brian Barry's dictum that 'democratic states that still have an open future have every reason for pursuing the course that leads to a linguistically homogeneous polity' (2001, p. 228). Such a territorialist would typically be inclined to endorse the second solution in states that still have that 'open future'.

\section{Territoriality and personality in Belgium}

Having proposed a conceptualization of territoriality and personality, I now move on to understand the past and current Belgian language policy based on these two concepts, first from the point of the language regime issue, and then from the point of view of the language border issue.

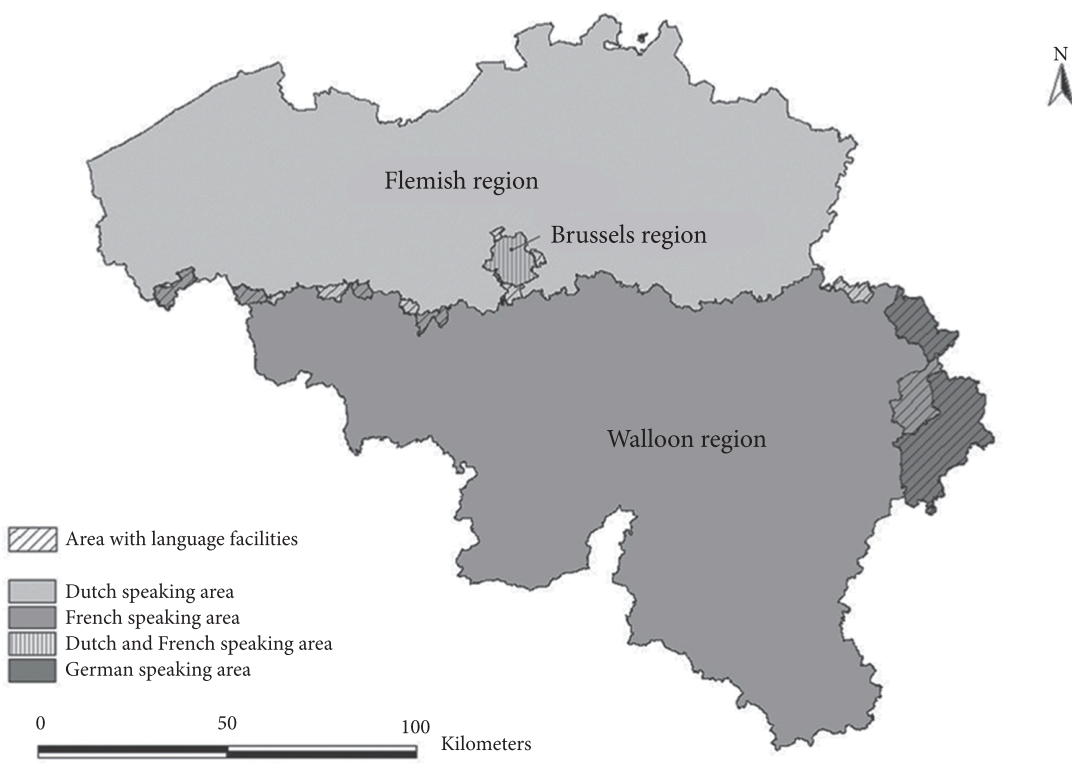

$\stackrel{N}{\Lambda}$

Map 1. Map of the Belgian language areas (VUB Geografisch Instituut, Janssens, 2018, p.67) 


\subsection{The language regime issue in Belgium}

Today Belgium has over 11.5 million inhabitants. Of these, 6.7 million live in the Flemish Region, 3.6 million in the Walloon Region and 1.2 million in the BrusselsCapital Region where French is the dominant language. Belgium has three official languages: Dutch, French and German. ${ }^{8}$

The Belgian constitution (article 30) mentions explicitly that language use is free (in Dutch vrij, in French facultatif, in German frei) - meaning that individuals can privately speak whatever language they wish. Language use can (only) be regulated by law for certain matters (see van der Jeught, 2017, pp.186-187). These matters include public administration (e.g. the language of governmental service) and public authority (e.g. language use in the army), publicly subsidized education, court proceedings, and work contacts between employers and employees (including for instance the language in which job contracts are drafted) (articles 30 and $129 \S 1$; see van der Jeught, 2017, pp.187-191). For the purposes of regulating these matters, the constitution (article 4) has divided Belgian territory into four official 'language areas' (taalgebieden in Dutch, régions linguistiques in French, Sprachgebiete in German): the Dutch language area (which is identical to the area covered by the Flemish Region), the French language area (which is part of the Walloon Region), the German language area (which is also part of the Walloon Region), and the bilingual Brussels-capital area (which is identical to the area covered by the Brussels Capital Region). The boundaries of these areas can only be changed through a federal law with majorities in each of the two major language groups (Dutch and French). Of these four language areas, the first three are called monolingual, even though these also include in total 27 municipalities with official language services in another of the three official languages which in Belgium are called 'facilities' (faciliteiten; facilités; Fazilitäten). The Brusselscapital Region is the only bilingual area and recognizes both Dutch and French.

Applying the continuum model of personality and territoriality developed above to this distribution of language areas in Belgium allows us to formulate a tripartite categorization of language regimes in Belgium: territoriality, personality and mixed.

\subsubsection{The linguistic territoriality regime}

This applies to those municipalities that belong to a monolingual language area and where no language facilities exist. It represents the position of most - 535

8. The words 'Dutch', 'French' and 'German' can refer to languages as well as to citizens of neighboring countries, respectively, the Netherlands, France and Germany. In this paper I use them only to refer to the languages. 
out of 581 - Belgian municipalities, all of them situated in the Dutch and French language areas. In these municipalities, only one language enjoys public recognition: Dutch in the north, French in the south. This means, for instance, that there are no publicly subsidized schools or universities in French in Bruges, Antwerp, Ghent and Leuven. Conversely, pupils in Mons, Namur or Liège cannot attend state-funded schools and universities that operate in Dutch. (In Belgium no significant fee-based school tradition exists.) In addition, citizens can only get documents from the authorities (whether from the regional or the federal administration) in the language of the language area. Civil court cases are tried in that same language. Job contracts in the private sector must be drafted in Dutch in the north and in French in the south (though the use of additional languages is allowed when international employment is concerned, see van der Jeught, 2017, pp.190-191).

In this part of the territory, then, a strict cujus regio ejus lingua principle applies. These municipalities provide the clearest illustration of the linguistic territoriality principle: within them, only one official language exists: Dutch in the north, French in the south

\subsubsection{The linguistic personality regime}

This applies in the bilingual Brussels-capital area (containing 19 municipalities), where language recognition is extended to two languages: French, which is the main lingua franca in Brussels, and Dutch, which is in a clear minority opposition (for recent figures see Janssens, 2018, pp.72-73). Importantly, no official registration exists of who is a Dutch and who is a French speaker; there is no 'subnationality' in Brussels on which rights or entitlements would depend - for instance, identity cards do not mention which language group citizens belong to. People can thus reformulate their own identity against the background of public support for both languages. They might, for instance, make use of a French hospital, vote for Dutch-speaking politicians, get a museum brochure in French, take publiclysubsidized Dutch piano lessons, and talk to city administrators in French. Court cases are tried in the language of choice of the defendant. Inhabitants can also choose Dutch or French schooling, from nurseries up to universities. There is no requirement for French speakers to send their children to French schools, or for Dutch speakers to attend Dutch schools.

This personality-enhancing liberty principle was for a brief period (1963-1970) replaced by a system that checked whether the language of the child was also the school language, which had the purpose of counteracting the francisation of Brussels, through a Quebec-style prohibition on Dutch speakers sending their children to French schools. But this liberté was reintroduced in 1970 because of strong disapproval by francophones and also by Dutch speakers who wanted 
to enable their children to use French to climb the social ladder (Witte and Van Velthoven, 1998, p.160). In practice, though, this freedom did not lead to a mass shift from Dutch-language education. Instead, many French speakers enrolled their children in Dutch schools for several reasons, including the higher quality of language education in those schools, the lower number of immigrants, and the socially-promoted need for bilingualism as a career requirement (see Witte and Van Velthoven, 1998, p.161; De Schutter, 2001).

This bilingual set-up, then, follows the personality principle as described above. Rather than declaring one official language for the territory and requiring the speaker to adapt to this, in Brussels the government provides equal services to the inhabitants in their own language in so far as that language is Dutch or French - the language regime exhibits the equal services approach discussed above, although the Brussels practice does not always live up to the theory. In this part of the country, then, the territory equally recognizes two public languages. This is an example of a strict personality regime.

\subsubsection{The mixed regime}

This applies to the 27 municipalities 'with facilities': 12 municipalities in the Dutch language area with facilities for French speakers, 6 in the French language area of which 4 with facilities for Dutch speakers and 2 with facilities for German speakers, and all 9 municipalities of the German language area, which have facilities for French speakers. Of these 27, the 6 municipalities in the Dutch language area surrounding Brussels with facilities for French speakers give rise to most debate. Notwithstanding the fact that the linguistic status of these municipalities is fixed, the traditionally Flemish concern is that these facilities send a signal that speakers of French do not need to linguistically 'integrate' and in fact that the facilities allow the process of demographic francisation to continue and enlarge the French 'oil stain' around Brussels into ever more of Flanders.

The facilities in these municipalities consist of services in another of the offcial Belgian languages. These provisions include, among other things, the right to receive documents in another language and to get public education at kindergarten and primary school level in a language other than the official language of the language area (under certain conditions, such as there being sufficient demand for this facility).

These facilities are exceptions to the otherwise monolingual regimes of the language areas to which they belong, and constitute breaches of the territoriality principle. But these breaches are not far-reaching enough to flip this regime to fully-fledged personality, as exists for instance in Brussels. The language of the language area maintains territorial primacy. For instance, the language of secondary education is determined by the language area, and the facilities are not 
granted to office holders or civil servants, who must use the language of the language area in their official capacities (Van der Jeught, 2017, p.188).

The facilities can be understood, then, as situated somewhere in the middle of the continuum between personality and territoriality: a mixed regime. Indeed, from the point of view of the linguistic territoriality principle, these facilities are personality-based perforations which replace 'pure' territoriality by a weaker form of this. But from the point of view of the linguistic personality principle, this regime still upholds the primacy of one language over the other and runs counter to the equal recognition ideal of personality: only 'weak personality' is installed. This combination of the two principles is the reason why this 'facilities' solution was invented in the first place in the 1963 language act: it was a compromise position between the personality view typically adhered to by Francophones and the territoriality position traditionally held by Flemish parties (Witte and Van Veldhoven, 1998, p.139).



Figure 1.

\subsection{The language border question in Belgium}

Above I mentioned that there are two dimensions to the personality-territoriality distinction. The first is the language policy regime issue: I have applied this to Belgium and shown that, on the continuum from personality to territoriality, there are essentially three policy regime types in Belgium. But a satisfactory understanding of territoriality and personality in Belgium today would not be complete without discussing one crucial dimension to Belgian language legislation: the metaterritorial issue of border drawing. To understand Belgium and the emergence of its predominantly territoriality-based system, it is crucial to see that the Flemish position has historically strongly insisted on drawing clear legal and political boundaries around the language areas. The resulting language border was meant to set a limit on the encroachment of French, and thus to restrict the francisation process. (We shall see, though, that historically Francophones also insisted on territoriality in Wallonia, in order to avoid Dutch language services there.) So the Flemish ambition was to seek both to delineate a Flemish territory (the metaterritorial solution) and to make sure that on that territory insti- 
tutional monolingualism applies (territoriality as the preferred language regime principle). These two dimensions - the metaterritorial and the language policy regime issue - have to be understood in tandem. This ambition has ultimately succeeded for most of the territory, as a short history of the metaterritorial issue and its intrinsic connection to the language regime issue shows, in five stages, for which I employ the continuum model above.

\subsubsection{Belgium-wide de facto territoriality}

When Belgium was founded in 1830, the boundary for language policy was that of the Belgian state. Inside that one state-wide language border, the official language policy was language freedom, implemented as an alternative to the (pro-Dutch) language coercion that had characterized the United Kingdom of the Netherlands from which Belgium seceded in 1830. No language laws were foreseen; language use was fully free. But this freedom in practice came down to French monolingualism: the constitution was drafted only in French, the laws were written in French, courts operated through the medium of French and political and administrative governance was in French only (Witte and Van Velthoven, 1998, pp.49-51). De facto, French was the only official language (van der Jeught, 2017, p.184). We can label the resulting language policy regime in the first decades of Belgium's history one of de facto territoriality benefitting French. A Flemish selfconsciousness soon developed and resulted in what would come to be known as the 'Flemish movement' (Vlaamse Beweging), though at this stage it was mostly a literary and cultural phenomenon with few if any political demands.

\subsubsection{De facto territoriality in Wallonia, and a mixed regime benefitting French in Flanders}

A second phase in the language policy and border history of the country took place in the last quarter of the 19th century. In the south, the de facto French-only position continued unchanged. But in Flanders, as a result of a series of modest language laws that took into account the fact that the masses in Flanders did not speak French, the system of Belgian-wide territoriality shifted to a mixed regime. French still enjoyed strong primacy and public governance occurred in French but, increasingly, civil servants were expected to be able to communicate with the public in Dutch in Flanders. As a result of the first language law in 1873, criminal justice proceedings in Flemish provinces had to take place in Dutch, even though defendants could ask for French as a court language or allow their lawyer to plead in French, which most lawyers preferred (Raskin, 2012, pp. 140-141). The language law of 1883 decreed that secondary schools in Flanders would now teach a number of courses in Dutch, even though one could opt out of this and receive Frenchonly education in schools in Flanders (Witte and Van Velthoven, 1998, p.62). 
The capacity of French to retain such a strong position in Flanders was related to the important fact that the language issue was also a social issue. In Flanders, French was the higher-status language. French was not a foreign language to Flanders; it was socially embedded there because all Flemish elites used it. The families of doctors, notaries, civil servants, teachers and lawyers would speak French; the working classes would speak dialects of Dutch. Access to the top positions was restricted to those who spoke French, either as their home language or by having acquired it. The elite in the south of the country, where the lower classes also spoke (Gallo-Romance) dialects and not the French standard, was therefore linguistically indistinguishable from the elite in the north (Raskin, 2012, p.129).

In short, in this second phase, a mixed regime was implemented, with important personality concessions for Dutch speakers in Flanders, though still on the basis of French primacy. Compared with the first phase, we are now moving leftwards on the continuum between personality and territoriality.

\subsubsection{Formal personality, de facto territoriality in Wallonia}

Increased sensitivity to the language question and mobilization especially on the Flemish side for reasons of identity and social opportunities led to the 1898 language act, which formally proclaimed linguistic equality between Dutch and French in Belgium. Despite its symbolic significance, this law was ultimately limited: it held that laws had to be voted and officially announced in both Dutch and French, and that the two versions had the same legal authority (Raskin, 2012, p.168).

In the following decade, a debate developed over whether Belgium was to be bilingual throughout, with a Belgium-wide linguistic personality principle. A government attempt to implement such a system failed due to resistance in the south. While a Belgium-wide personality regime would have allowed Francophones in the north to access public services in French, it would also have required the provision of public services in Dutch to the thousands of Flemish, who had moved to the south in order to labor in industrial centers such as Charleroi or Liège. For that reason, and its implication that the personality principle would require proficiency in Dutch for Walloon public servants, the Walloon side rejected personality for Wallonia in favor of Walloon territoriality (Witte and Van Velthoven, 1998, 71-72; 79-83). In Wallonia, French was to enjoy exclusive recognition.

\subsubsection{A mixed regime benefitting Dutch in Flanders; De facto territoriality in Wallonia}

In 1921, an important new law put forward the principle that the regional language is to be the official language (streektaal is voertaal), thus installing elements of territoriality in both parts of the country. Yet, it allowed personality perforations. 
For example, French speakers in Flanders could access government documents in French, and municipal councils could decide to be internally bilingual. Similar personality exceptions applied to Dutch speakers in Wallonia, but in practice they were invoked only for and by Francophones in Flanders (Raskin, 2012, pp.190-191). It can thus be understood as a mixed regime in Flanders: territorial primacy for Dutch with personality perforations for Francophones.

\subsubsection{Territoriality in Flanders and Wallonia; Personality in Brussels; the mixed regime in the municipalities with facilities}

The final stage saw a rightward swing-back of the pendulum: towards full territoriality, though this time (in contrast with the first phase) not within a Belgianwide border but within Flemish and Walloon borders respectively. Personality was restricted to Brussels. This change was given effect through the language laws of 1932 and 1962.

In 1932, a firm principle of linguistic territoriality was established that closed the personality perforations of 1921: from now on the regional language became the only language of education, administration, and (from 1935) the judicial system. French speakers in the north could no longer access public services in French, and French schools in Flanders were in most cases abolished.

But there was a catch: the system allowed for language border changes. If the decennial population censuses revealed that $30 \%$ of a municipality's inhabitants belonged to a different language group, the municipality had to allow the minority access to state services in the minority language. Once a majority was reached, the other language would now become the official language of the municipality (Witte and Van Velthoven, 1998, p. 106). This system, however, was met by strong resistance on the Flemish side, which saw it as a catalyst of francization, with the enlargement of Brussels in the neighboring Flemish hinterland. Indeed, the 1947 census indicated that Flanders had to cede several municipalities, allowing the language border to move northwards. As a result, a strong Flemish demand backed up by mass language marches - grew for a clear and unchangeable language border. This resulted in the 1961-1963 language acts, which reaffirmed linguistic territoriality within the two language areas, abolished the language question in the census, and after some final border adjustments, fixed the language border once and for all. The border of Brussels was fixed as well, and the system of 27 municipalities was born. At this stage, the existence of the bilingual university of Leuven in the Dutch language area was still a thorn in the side of Flemish territorialists, but this issue would be 'territorialized' in the 196os, with the division of the university into two monolingual universities in 1968, one in the Dutch and one in the French language area. 
The Belgian case shows clearly how the language border issue and the language regime question are entangled: the system endorsed the policy regime principle of linguistic territoriality, mandating official unilingualism, but also enabled border (re)drawing in order to arrive at a clear territorial separation of Belgium's language policy regimes. The new borders also provided the backdrop against which the country could, from 1970 onwards, change from a unitary into a federal state.

\section{Conclusion}

In this contribution I have proposed that, as language policy regimes, the linguistic personality principle and the linguistic territoriality principle occupy the poles on a continuum between official multilingualism and official monolingualism, with mixed regimes in between. Moreover, those who support territoriality for language identity reasons will couple monolingualism with the metaterritorial solution of (re)drawing boundaries in such a way as to delineate language groups. I have then applied this theoretical model to Belgium. From de facto territoriality benefitting French in a Belgian-wide territory in 1830, the system shifted leftwards on the continuum to a position of personality in Flanders and Brussels (but de facto territoriality in Wallonia), and then rightwards again, after some border redrawing in the early 1960s, resulting in the current language policy structure: strict territoriality in almost all of Belgium supported by fixed language borders. There are still two important exceptions to strict territoriality in Belgium, though: the personality principle reigns in Brussels, and a mixed regime applies in 27 municipalities with linguistic facilities.

\section{Funding}

Open Access publication of this article was funded through a Transformative Agreement with KU Leuven.

\section{References}

Barry, B. (2001). Culture and equality. An egalitarian critique of multiculturalism. Cambridge: Polity Press.

Burckhardt, T., Coakley, J. and Maracz, L. (2021). Inguistic territoriality under stress: European perspectives, Language Problems and Language Planning 45 (3), 121-142. 
De Schutter, H. (2001). Taalpolitiek en multiculturalisme in het Brussels Nederlandstalige onderwijs. In: E. Witte \& A. Mares (Eds.), Brusselse Thema's 6. Twintig jaar onderzoek over Brussel (pp. 155-167).

De Schutter, H. (2017). Two principles of equal language recognition. Critical Review of International Social and Political Philosophy, 20 (1), 75-87. https://doi.org/10.1080/13698230.2016.1253166

Grin, F. (2011). Using territoriality to support genuine linguistic diversity, not to get rid of it. In: P. De Grauwe and P. Van Parijs (Eds.), The linguistic territoriality principle: Right violation or parity of esteem? Re-Bel E-book 11 (pp. 28-33). Brussels: University Foundation.

Janssens, R. (2018). The impact of mobility and migration on the identity-constructing policy in Brussels. In P.A. Kraus and F. Grin, The politics of multilingualism. Europeanisation, globalisation and linguistic governance (pp. 65-88). Amsterdam/Philadelphia: John Benjamins. https://doi.org/10.1075/wlp.6.04jan

Kymlicka, W. (2001). Politics in the vernacular. Oxford: Oxford University Press. https://doi.org/10.1093/0199240981.001.0001

Laponce, J.A. (1987). More about languages and their territories: A reply to Pattanayak and Bayer. Political Geography Quarterly, 6 (3), 265-267. https://doi.org/10.1016/S0260-9827(87)80005-8

McRae, K. (1975). The principle of territoriality and the principle of personality in multilingual states. International Journal of the Sociology of Language, 4, 33-54.

McRae, K. (2007). Toward language equality: Four democracies compared. International Journal for the Sociology of Language, 187/188, 13-34. https://doi.org/10.1515/IJSL.2007.048

Patten, A. (2003). What kind of bilingualism?, in W. Kymlicka and A. Patten (Eds.), Language rights and political theory (pp. 296-321). Oxford: Oxford University Press.

Patten, A. (2014). Equal recognition: The moral foundations of minority rights. Princeton: Princeton University Press.

Raskin, B. (2012). De taalgrens: of wat de Belgen zowel verbindt als verdeelt. Leuven: Davidsfonds.

Réaume, D. (2003). Beyond personality: The territorial and personal principles of language policy reconsidered. In W. Kymlicka \& A. Patten (Eds.), Language rights and political theory (pp. 271-295). Oxford: Oxford University Press.

Renner, K. (2005 [1899]). State and nation. In E. Nimni (Ed.), National cultural autonomy and its contemporary critics (pp. 15-48). London: Routledge.

Royal Commission on Bilingualism and Biculturalism. (1967). Report. Accessed on 5 July 2021 at https://epe.lac-bac.gc.ca/10o/200/301/pco-bcp/commissions-ef/dunton1967-1970-eng /dunton1967-70-eng.html

van der Jeught, S. (2017). Territoriality and freedom of language: The case of Belgium, Current Issues in Language Planning, 18 (2), 181-198. https://doi.org/10.1080/14664208.2016.1243883

Van Parijs, Ph. (2004). Europe's linguistic challenge. European Journal of Sociology / Archives Européennes de Sociologie / Europäisches Archiv für Soziologie, 45 (1), 113-154. https://doi.org/10.1017/So003975604001407

Van Parijs, Ph. (2011). Linguistic justice for Europe and for the world. Oxford: Oxford University Press. https://doi.org/10.1093/acprof:osobl/9780199208876.001.0001

Witte, E. and Van Velthoven, H. (1998). Taal en politiek. De Belgische casus in een historisch perspectief. Brussel: Balans/VUBPRESS. 


\section{Samenvatting}

Taalbeleidsdebatten refereren vaak naar het personaliteitsbeginsel en het territorialiteitsbeginsel. Toch blijft hun precieze betekenis onduidelijk. In deze bijdrage conceptualiseer ik deze beginselen als polen van een continuum tussen officiële tweetaligheid (het personaliteitsbeginsel) en officiële eentaligheid (het territorialiteitsbeginsel), met daartussenin een regime dat een zekere territoriale primauteit toekent aan een taal maar toch uitzonderingen daarop toelaat op basis van talige aanhorigheid. De vraag naar de positiebepaling op het continuum kan niet los worden gezien van de metaterritoriale vraag naar de grenzen van de eenheden waarbinnen die beginselen zullen gelden. De toepassing van dit 'continuummodel' op de taalpolitieke regimes die gelden in België laat mij toe te drie regimes te onderscheiden. Het eerste volgt het strikte personaliteitsbeginsel: dat geldt in Brussel. Het tweede implementeert het strikte territorialiteitsbeginsel: dat is van toepassing in bijna alle gemeenten van Vlaanderen en Wallonië. Het derde is het tussenregime, dat in totaal 27 faciliteitengemeenten kenmerkt waar steeds één taal primauteit geniet maar sprekers van een andere landstaal bepaalde 'taalfaciliteiten' genieten. Ook geef ik aan hoe in België deze regimes historisch tot stand kwamen in combinatie met een vastlegging van de taalgrens en de indeling van België in vier taalgebieden.

\section{Resumo}

Lingvopolitikaj debatoj regule aludas al la principoj de personeco kaj teritorieco. Sed la preciza signifo de tiuj principoj restas neklara. En la nuna kontribuo, mi konceptas tiujn principojn kiel polusojn de kontinuo inter oficiala dulingvismo (reprezenta de la personeca principo) kaj oficiala unulingvismo (ekzempliga de la teritoria principo), inter kiuj regas miksita reĝimo (kiu cedas difinitan teritorian superecon al difinita lingvo sed permesas esceptojn pro lingva filiiĝo). La demando pri determinado de difinitaj punktoj en la kontinuo ne estas apartigebla disde la metateritoria demando pri la limoj de la unuoj ene de kiuj la principoj aplikiĝas. Apliko de tiu 'kontinua modelo' al Belgio tiras la atenton al tri lingvopolitikaj reĝimoj. La unua elvokas striktan personecan principon (Bruselo). La dua sekvas strikte teritorian principon (preskaŭ ćiuj municipoj en Flandrio kaj Valonio). La tria estas miksita reĝimo (sume 27 'municipoj kun faciligiloj' kie unu lingvo guas primaran rolon sed la parolantoj de alia lingvo ĝuas certajn lingvajn 'faciligilojn'). La artikolo analizas ankaŭ la manieron laŭ kiu tiuj reĝimoj historie establiĝis en Belgio en kombino kun difinado de la lingva bordo kaj divido de la lando en kvar lingvajn areojn. 
Address for correspondence

Helder De Schutter

Institute of Philosophy

KU Leuven

Kard. Mercierplein 2

3000 Leuven

Belgium

helder.deschutter@kuleuven.be

\section{Publication history}

Date received: 1 May 2021

Date accepted: 31 July 2021 